\title{
C-SECTION PREFEREANCE REASONS OF WOMEN: A SCALE DEVELOPMENT STUDY ${ }^{(1)}$
}

\section{KADINLARIN SEZARYEN TERCIIH NEDENLERİ: BİR ÖLÇEK GELIŞTIIRME ÇALIŞMASI}

\author{
Ümran SEVILL ${ }^{1}$, Vasfiye BAYRAM DEĞER², Ali Serdar YÜCEL ${ }^{3}$, Ayça GÜRKAN \\ Dilek ÖZTAŞ ${ }^{5}$, Murat KORKMAZ ${ }^{6}$, Perihan ABAY \\ 1-4 Istanbul University of Health and Technology, Faculty of Health Sciences, İstanbul / Turkey \\ ${ }^{2}$ Mardin Artuklu University, Faculty of Health Sciences, Mardin / Turkey \\ ${ }^{3}$ Firat University, Faculty of Sports Sciences, Elazı̆ / Turkey \\ ${ }^{5}$ Ankara Yuldurtm Beyaztt University, Faculty of Medicine, Ankara / Turkey \\ ${ }^{6}$ Güven Plus Group Counselling Inc. İstanbul / Turkey \\ ${ }^{7}$ Kanuni Sultan Süleyman Research and Training Hospital, İstanbul / Turkey
}

ORCID ID: 0000-0002-8973-3002', 0000-0002-7714-9087², 0000-0002-4543-412333, 0000-0001-6962-3095 $, 0000-0002-8687-7238^{5}, 0000-0001-7925-5142^{6}$, 0000-0002-7407-9175
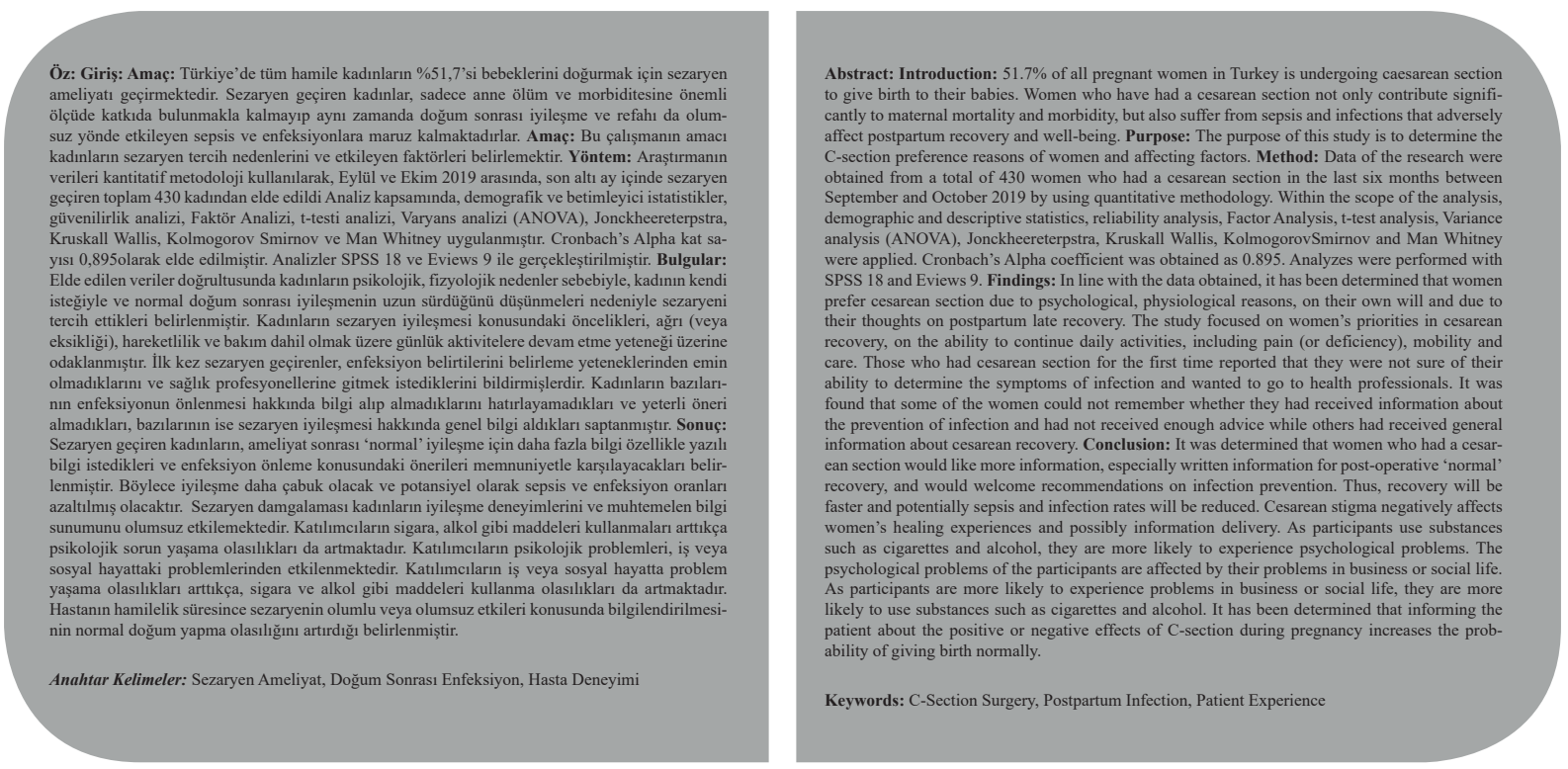

Doi: $10.17363 / S S T B .2020 .35 .2$

(1) Sorumlu Yazar, Corresponding Author: Ümran SEVIL “Prof. Dr. Proffessor”, Istanbul University of Health and Technology, Faculty of Health Sciences, Istanbul / Turkey, umransevil@gmail.com, Geliş Tarihi / Received: 22.12.2019, Kabul Tarihi / Accepted: 15.06.2020, Makalenin Türü: Type of Article: (Araştırma ve Uygulama / Research and Application) Çıkar Çatısması / Conflict of Interest: Yok/No, Etik Kurul Raporu veya Kurum İzin Bilgisi - Ethical Board Report or Institutiunal Approval, Var/Yes, “Mardin Artuklu University, Ethical Board Decision No: 34233153-730.03.02, Decision No: 2018/1-4, Date: 22.02.2018” 


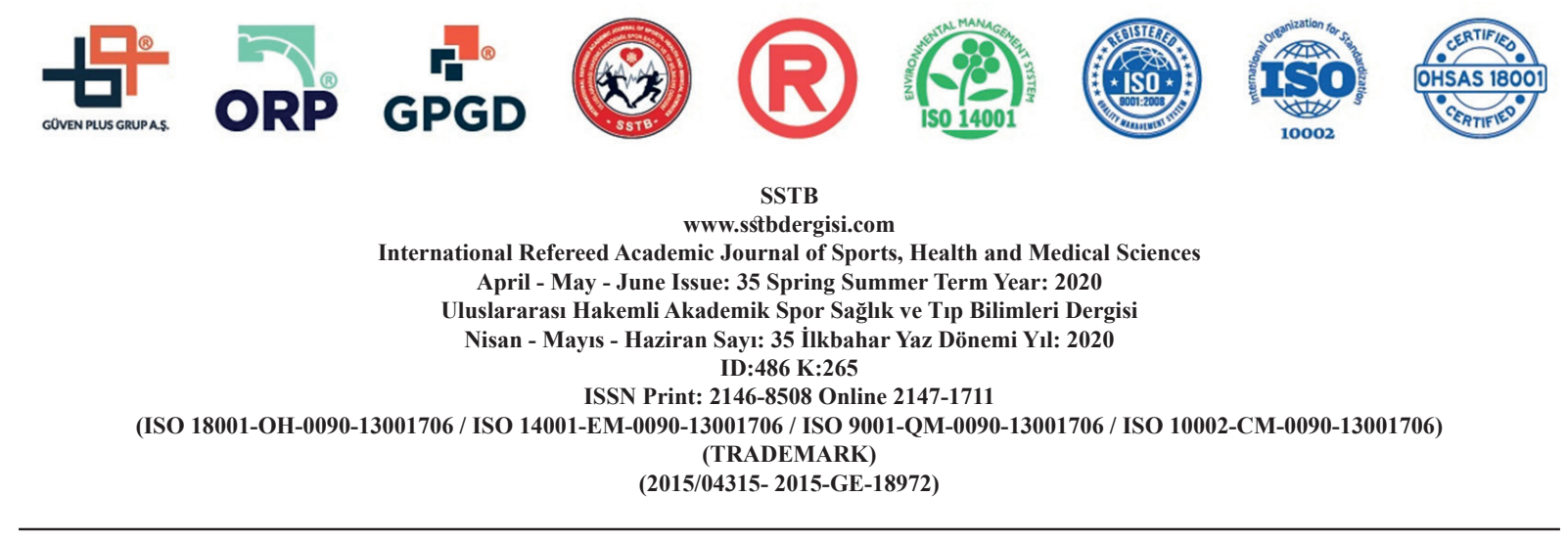

INTRODUCTION and THEORETICAL FRAMEWORK

During pregnancy, women often feel complicated feelings about birth, new lifestyle and new responsibilities. Birth is an important emotional event in a woman's life and is a normal psychosocial process. Fear of birth and ambient feelings about birth are a normal part of the pregnancy process (Kasai, 2010). The action of birth is a process that may expose the woman to many risks during pregnancy, at birth and in postpartum period (Sönmez and Sivaslıoğlu, 2019). Pregnant women experience fear and anxiety about how the delivery will be during the pregnancy. Especially in her first pregnancy, a woman experiences many new sensations she cannot define and does not know what to encounter at birth (Sönmez and Sivaslığlu, 2019). In addition, many factors are effective for women to decide the appropriate delivery method (Elkin, 2016: 120). Regarding the fact that birth is a painful and difficult process, the negative experiences of women about vaginal delivery during pregnancy direct their preferences to cesarean delivery in relation to the idea that they will also experience this process (Say1ner and Özerdoğan, 2009). In the study of Ergöl, Ş., Kürtüncü, M., (2014), it has been determined that the fear from birth and the pain experienced at birth is significantly effective in C-section preferences of women.
There can be many reasons for the continuous increase in cesarean delivery rates. Some of the possible reasons can be listed as advanced maternal age, never having given birth before, obesity, anxiety of genital changes caused by vaginal delivery, the idea that cesarean delivery is more reliable for the baby, the idea that it is a more suitable method for mother and healthcare professionals, fear of medical litigation, desire to have a completely healthy baby, reduced tolerance to any complications or possible negative results (Karabel et al., 2017), predetermination of cesarean period and time, fear of birth pain, low or absence of possibility of delivery with epidural anesthesia and poor obstetric memories experienced in previous births (Tekin, 2006).

In addition to the undesired problems such as delayed onset of breastfeeding and mother-baby relationship and existence of risk factors for future births, cesarean delivery increases maternal mortality 4 times compared to vaginal birth (Gözükara and Eroğlu, 2008). While the possibility of giving birth by cesarean increases due to many factors, it is reported that $45 \%$ of the first births are performed by C-section (Cited by Karabulutlu, 2012 from TNSA, 2008).

According to data of Turkey Demographic Health Survey, the cesarean rate in 2003 was $21.2 \%$, and $37 \%$ in 2008 (Ergöçmen et al., 2009). The rate of C-section delivery among all births was $16 \%$ in the world regarding the 


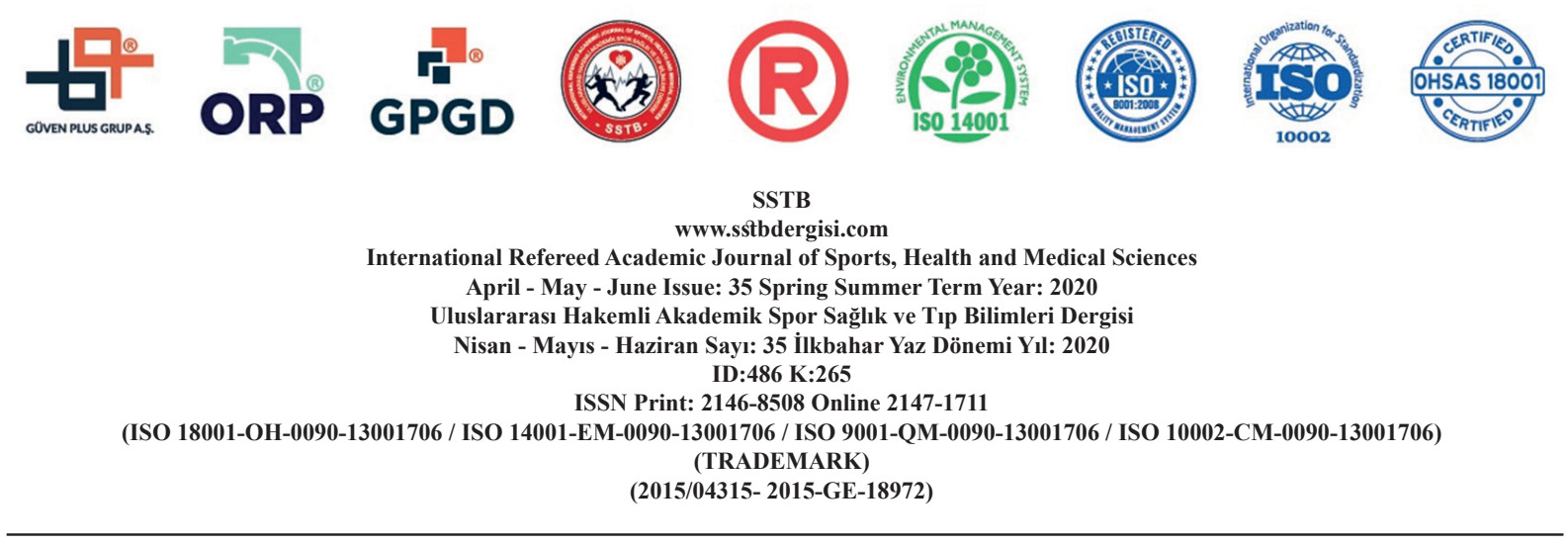

data of 2010 while it was $47 \%$ in Turkey in 2011 (Başara et al., 2012). It was found as $48 \%$ in 2013 (www.hips.hacettepe.edu.tr, 13.05.2020).

It is known that the frequency of normal births has decreased and the tendency of cesarean delivery has increased in Turkey and in the world. To prevent the increase in cesarean delivery rate, it is very important to know the effective factors (Elkin, 2016: 126). In our country, the purpose is to decrease the cesarean rates to $27 \%$ in 2017 and $20 \%$ in 2023 and to increase normal and natural births (T.R. Ministry of Health 2012).

All these results reveal the importance of personal preference in increasing cesarean rates in recent years. One of the factors that affect the caesarean rate is the preference of the mother. Gradual increase in cesarean rates in women and preferring cesarean delivery voluntarily is an issue that should be emphasized (Tekin, 2006). It is important that the pregnant women are well-informed correctly and directed towards the appropriate delivery method and the delivery is carried out in a healthy way. Factors affecting the preference of cesarean delivery should be determined (Dölen and Özdeğirmenci, 2004) and national programs should be developed in order for the efforts to decrease the rates of cesarean delivery without medical reasons to be successful (Elkin, 2016: 120).

\section{APPLICATION RESULTS}

Table 1. Reliability Analysis

\begin{tabular}{ll}
\hline $\begin{array}{l}\text { Cronbach's } \\
\text { Alpha }\end{array}$ & $\begin{array}{l}\text { Number of } \\
\text { Items }\end{array}$ \\
\hline, 895 & 30
\end{tabular}

Looking at the results of reliability analysis, 30 items included in the analysis have been found to be at highly reliable.

\section{Demographic Statistics}

Demographic statistics of the participants are presented below. The profile of the participants are as follows;

- $\quad 9 \%$ of them are in business life for 1-3 years, $34 \%$ for $4-6$ years, $17 \%$ for $7-9$ years, $13 \%$ for $10-12$ years, $11 \%$ for $13-15$ years, $7 \%$ for $16-20$ years and $8 \%$ for $21+$ years.

- $3 \%$ is working in Public sector, $25 \%$ in Private sector, $33 \%$ is Freelancer, $32 \%$ is not working and $7 \%$ is in other sectors.

- $8 \%$ is primary school graduate, $18 \%$ is high school graduate, $40 \%$ is college graduate, $28 \%$ is university graduate and $6 \%$ is literate.

- $6 \%$ of them earn $1301-1800,29 \%$ earns 1801-2000, 36\% earns 2001-2500, 20\% earns 2501-3000 and 9\% earns 800$1300 \mathrm{TL}$. 


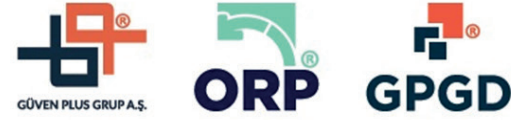

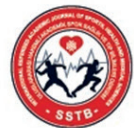

www.sstbdergisi.com

International Refereed Academic Journal of Sports, Health and Medical Sciences

April - May - June Issue: 35 Spring Summer Term Year: 2020

Uluslararası Hakemli Akademik Spor Sağlık ve Tıp Bilimleri Dergisi

Nisan - Mayıs - Haziran Sayı: 35 İlkbahar Yaz Dönemi Yıl: 2020 ID:486 K:265

ISSN Print: 2146-8508 Online 2147-1711

(ISO 18001-OH-0090-13001706 / ISO 14001-EM-0090-13001706 / ISO 9001-QM-0090-13001706 / ISO 10002-CM-0090-13001706) (TRADEMARK)

(2015/04315- 2015-GE-18972)

- $26 \%$ is married for 1 year, $52 \%$ for $2-4$ years, $10 \%$ for $5-8$ years, $7 \%$ for $9-12$ years, and $5 \%$ for $13+$ years.
- $12 \%$ is in the age group of $18-20,28 \%$ in $21-25,36 \%$ in $26-30,13 \%$ in $31-35$, $6 \%$ in $36-40$ and $4 \%$ is in the age group of $41+$.

Table 2. Demographic Statistics

\begin{tabular}{|c|c|c|c|}
\hline & Option & Frequency & $\begin{array}{l}\text { Column } \\
\mathrm{N} \%\end{array}$ \\
\hline \multirow{7}{*}{$\begin{array}{l}\text { HOW LONG HAVE YOU BEEN IN BUSINESS } \\
\text { LIFE? }\end{array}$} & $1-3$ years & 39 & $9 \%$ \\
\hline & 4-6 years & 147 & $34 \%$ \\
\hline & $7-9$ years & 74 & $17 \%$ \\
\hline & 10-12 years & 58 & $13 \%$ \\
\hline & 13-15 years & 48 & $11 \%$ \\
\hline & $16-20$ years & 30 & $7 \%$ \\
\hline & $21+$ years & 34 & $8 \%$ \\
\hline \multirow[t]{5}{*}{ IN WHICH SECTOR DO YOU WORK? } & Public & 13 & $3 \%$ \\
\hline & Private & 108 & $25 \%$ \\
\hline & $\begin{array}{l}\text { Not work- } \\
\text { ing }\end{array}$ & 137 & $32 \%$ \\
\hline & Freelancer & 141 & $33 \%$ \\
\hline & Other & 31 & $7 \%$ \\
\hline \multirow[t]{5}{*}{ WHAT IS YOUR EDUCATION LEVEL? } & $\begin{array}{l}\text { Primary } \\
\text { school }\end{array}$ & 36 & $8 \%$ \\
\hline & High school & 78 & $18 \%$ \\
\hline & College & 170 & $40 \%$ \\
\hline & University & 120 & $28 \%$ \\
\hline & Literate & 26 & $6 \%$ \\
\hline \multirow[t]{4}{*}{ WHAT IS YOUR INCOME? } & $1301-1800$ & 25 & $6 \%$ \\
\hline & $1801-2000$ & 126 & $29 \%$ \\
\hline & $2001-2500$ & 154 & $36 \%$ \\
\hline & $2501-3000$ & 86 & $20 \%$ \\
\hline
\end{tabular}




\section{些}
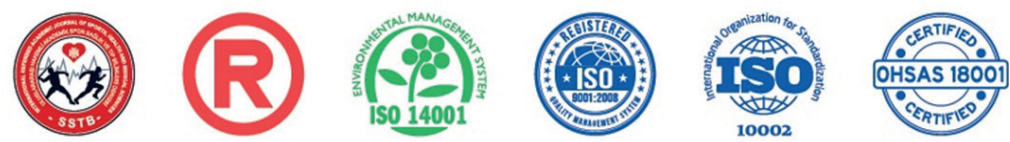

SSTB

www.sstbdergisi.com

International Refereed Academic Journal of Sports, Health and Medical Sciences April - May - June Issue: 35 Spring Summer Term Year: 2020

Uluslararası Hakemli Akademik Spor Sağlık ve Tıp Bilimleri Dergisi

Nisan - Mayıs - Haziran Sayı: 35 İlkbahar Yaz Dönemi Yıl: 2020 ID:486 K:265

ISSN Print: 2146-8508 Online 2147-1711

(ISO 18001-OH-0090-13001706 / ISO 14001-EM-0090-13001706 / ISO 9001-QM-0090-13001706 / ISO 10002-CM-0090-13001706) (TRADEMARK)

(2015/04315- 2015-GE-18972)

\begin{tabular}{llll}
\hline & $800-1300$ & 39 & $9 \%$ \\
\hline HOW LONG HAVE YOU BEEN MARRIED? & 1 year & 113 & $26 \%$ \\
\hline & $2-4$ years & 224 & $52 \%$ \\
\hline & $5-8$ years & 43 & $10 \%$ \\
\hline HOW OLD ARE YOU? & $9-12$ years & 29 & $7 \%$ \\
\hline & $13+$ & 21 & $5 \%$ \\
\hline & $18-20$ & 51 & $12 \%$ \\
\hline & $21-25$ & 119 & $28 \%$ \\
\hline & $26-30$ & 156 & $36 \%$ \\
\hline & $31-35$ & 58 & $13 \%$ \\
\hline & $36-40$ & 27 & $6 \%$ \\
\hline & $41+$ & 19 & $4 \%$
\end{tabular}

Table 3. Statistics about Pregnancy Period

\begin{tabular}{|c|c|c|c|}
\hline & Option & $\begin{array}{l}\text { Fre- } \\
\text { quen- } \\
\text { cy }\end{array}$ & $\begin{array}{l}\text { Col- } \\
\text { umn N } \\
\%\end{array}$ \\
\hline \multirow[t]{4}{*}{ IS THIS YOUR FIRST PREGNANCY? } & First & 212 & $49 \%$ \\
\hline & Second & 157 & $37 \%$ \\
\hline & Third & 46 & $11 \%$ \\
\hline & Fourth & 15 & $3 \%$ \\
\hline \multirow{2}{*}{$\begin{array}{l}\text { HAVE YOU EVER EXPERIENCED MISCARRIAGE OR } \\
\text { ABORTION? }\end{array}$} & Yes & 194 & $45 \%$ \\
\hline & No & 236 & $55 \%$ \\
\hline \multirow{5}{*}{$\begin{array}{l}\text { WHAT KIND OF NUTRITION DO YOU TAKE DURING } \\
\text { PREGNANCY? }\end{array}$} & Fruits and vegetables & 56 & $13 \%$ \\
\hline & Meat and dairy products & 129 & $30 \%$ \\
\hline & $\begin{array}{l}\text { Convenience foods and } \\
\text { products }\end{array}$ & 154 & $36 \%$ \\
\hline & Liquids and desserts & 75 & $17 \%$ \\
\hline & Other products & 16 & $4 \%$ \\
\hline
\end{tabular}




\section{些}
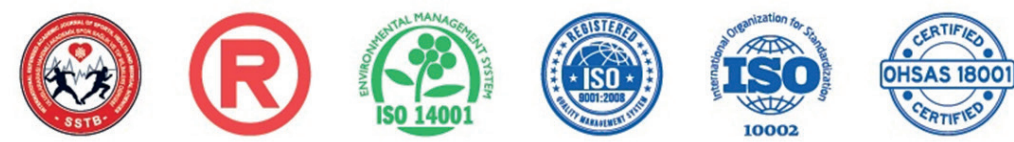

www.sstbdergisi.com

International Refereed Academic Journal of Sports, Health and Medical Sciences

April - May - June Issue: 35 Spring Summer Term Year: 2020

Uluslararası Hakemli Akademik Spor Sağlık ve Tıp Bilimleri Dergisi

Nisan - Mayıs - Haziran Sayı: 35 İlkbahar Yaz Dönemi Yıl: 2020 ID:486 K:265

ISSN Print: 2146-8508 Online 2147-1711

(ISO 18001-OH-0090-13001706 / ISO 14001-EM-0090-13001706 / ISO 9001-QM-0090-13001706 / ISO 10002-CM-0090-13001706) (TRADEMARK)

(2015/04315- 2015-GE-18972)

\begin{tabular}{|c|c|c|c|}
\hline \multirow{2}{*}{$\begin{array}{l}\text { DO YOU BENEFIT FROM PRIVATE HEALTH INSUR- } \\
\text { ANCE? }\end{array}$} & Yes & 150 & $35 \%$ \\
\hline & No & 280 & $65 \%$ \\
\hline \multirow{2}{*}{$\begin{array}{l}\text { HAVE YOU HAD ANY PSYCHOLOGICAL PROBLEMS } \\
\text { DURING YOUR PREGNANCY? }\end{array}$} & Yes & 102 & $24 \%$ \\
\hline & No & 328 & $76 \%$ \\
\hline \multirow{5}{*}{$\begin{array}{l}\text { WHICH OF THE FOLLOWING ITEMS DO YOU USE CON- } \\
\text { SISTENTLY? }\end{array}$} & Smoking & 201 & $47 \%$ \\
\hline & Alcohol & 3 & $1 \%$ \\
\hline & Smoking+alcohol & 20 & $5 \%$ \\
\hline & Other & 34 & $8 \%$ \\
\hline & None of them & 172 & $40 \%$ \\
\hline \multirow{2}{*}{$\begin{array}{l}\text { DO YOU HAVE SOCIAL AND FAMILY PROBLEMS } \\
\text { ABOUT YOUR JOB AND PROFESSION? }\end{array}$} & Yes & 102 & $24 \%$ \\
\hline & No & 328 & $76 \%$ \\
\hline \multirow{5}{*}{$\begin{array}{l}\text { DO YOU USE SOCIAL MEDIA? WHICH ONES DO YOU } \\
\text { USE IF SO? }\end{array}$} & Facebook & 58 & $13 \%$ \\
\hline & Twitter & 127 & $30 \%$ \\
\hline & YouTube & 161 & $37 \%$ \\
\hline & All of them & 14 & $3 \%$ \\
\hline & None of them & 70 & $16 \%$ \\
\hline \multirow[t]{4}{*}{ HOW MANY HOURS A DAY DO YOU EXERCISE? } & 1 hour & 153 & $36 \%$ \\
\hline & 2 hours & 22 & $5 \%$ \\
\hline & 3 hours & 30 & $7 \%$ \\
\hline & I don't do sports & 225 & $52 \%$ \\
\hline \multirow[t]{5}{*}{ WHAT KIND OF EXERCISES DO YOU GENERALLY DO? } & Walking & 58 & $13 \%$ \\
\hline & Swimming & 127 & $30 \%$ \\
\hline & $\begin{array}{l}\text { Fitness and other sports } \\
\text { activities }\end{array}$ & 161 & $37 \%$ \\
\hline & Running & 14 & $3 \%$ \\
\hline & Other & 70 & $16 \%$ \\
\hline
\end{tabular}


www.sstbdergisi.com

International Refereed Academic Journal of Sports, Health and Medical Sciences April - May - June Issue: 35 Spring Summer Term Year: 2020

Uluslararası Hakemli Akademik Spor Sağlık ve Tıp Bilimleri Dergisi

Nisan - Mayıs - Haziran Sayı: 35 İlkbahar Yaz Dönemi Yıl: 2020 ID:486 K:265

ISSN Print: 2146-8508 Online 2147-1711

(ISO 18001-OH-0090-13001706 / ISO 14001-EM-0090-13001706 / ISO 9001-QM-0090-13001706 / ISO 10002-CM-0090-13001706) (TRADEMARK)

(2015/04315- 2015-GE-18972)

\begin{tabular}{|c|c|c|c|}
\hline \multirow[t]{2}{*}{$\begin{array}{l}\text { DO OR DID THE SPORTS ACTIVITIES CONTRIBUTE TO } \\
\text { YOU PHYSICAL AND MENTALLY IN YOUR PREGNAN- } \\
\text { CY PERIOD? }\end{array}$} & Yes & 188 & $44 \%$ \\
\hline & No & 241 & $56 \%$ \\
\hline \multirow{2}{*}{$\begin{array}{l}\text { DO YOU THINK YOUR PREGNANCY WAS DIFFICULT } \\
\text { AND DISTRESSED? }\end{array}$} & Yes & 248 & $58 \%$ \\
\hline & No & 181 & $42 \%$ \\
\hline \multirow{2}{*}{$\begin{array}{l}\text { DO YOU FREQUENTLY GO TO YOUR DOCTOR FOR } \\
\text { ROUTINE CONTROLS IN PREGNANCY? }\end{array}$} & Yes & 196 & $46 \%$ \\
\hline & No & 234 & $54 \%$ \\
\hline \multirow[t]{3}{*}{ HAVE YOU GAINED EXCESS WEIGHT IN PREGNANCY? } & Yes & 239 & $56 \%$ \\
\hline & No & 186 & $43 \%$ \\
\hline & It was a normal process & 5 & $1 \%$ \\
\hline \multirow{2}{*}{$\begin{array}{l}\text { DO YOU PREFER C-SECTION IF NO MEDICAL OBLIGA- } \\
\text { TION EXISTS? }\end{array}$} & Yes & 310 & $72 \%$ \\
\hline & No & 120 & $28 \%$ \\
\hline \multirow{2}{*}{$\begin{array}{l}\text { DO YOU KNOW THAT VAGINAL BIRTH IS A BETTER DE- } \\
\text { CISION FOR YOU? }\end{array}$} & Yes & 411 & $96 \%$ \\
\hline & No & 19 & $4 \%$ \\
\hline \multirow{2}{*}{$\begin{array}{l}\text { DID YOUR DOCTOR INFORM YOU ABOUT C-SECTION } \\
\text { DELIVERY? }\end{array}$} & Yes & 412 & $96 \%$ \\
\hline & No & 18 & $4 \%$ \\
\hline \multirow[t]{2}{*}{$\begin{array}{l}\text { ARE YOU INFORMED ABOUT ANESTHESIA AND OTH- } \\
\text { ER MEDICAL COMPLICATIONS? }\end{array}$} & Yes & 196 & $46 \%$ \\
\hline & No & 234 & $54 \%$ \\
\hline
\end{tabular}

Participants were asked to answer a series of questions about how they went through their pregnancy processes. Accordingly;

- $49 \%$ of the participants are going through their first pregnancy, $37 \%$ of them second pregnancy, $11 \%$ third pregnancy and $3 \%$ of them are going through their fourth pregnancy.
- For the question 'Have you ever experienced miscarriage or abortion', $45 \%$ of the participants answered Yes.

- Regarding the nutrition of the participants, $13 \%$ of them mostly eat fruits and vegetables, $30 \%$ meat and dairy products heavily, $36 \%$ convenience foods and pro- 
International Refereed Academic Journal of Sports, Health and Medical Sciences April - May - June Issue: 35 Spring Summer Term Year: 2020

Uluslararası Hakemli Akademik Spor Sağlık ve Tıp Bilimleri Dergisi

Nisan - Mayıs - Haziran Sayı: 35 İlkbahar Yaz Dönemi Yıl: 2020 ID:486 K:265

ISSN Print: 2146-8508 Online 2147-1711

(ISO 18001-OH-0090-13001706 / ISO 14001-EM-0090-13001706 / ISO 9001-QM-0090-13001706 / ISO 10002-CM-0090-13001706) (TRADEMARK)

(2015/04315- 2015-GE-18972)

ducts, $17 \%$ liquids and desserts and $4 \%$ of them generally eat other products.

- $35 \%$ of the participants have private health insurance.

- $24 \%$ of them experienced a psychological problem during pregnancy.

- $\quad 47 \%$ of them smoked, $1 \%$ consumed alcohol, $5 \%$ used both smoking and alcohol and $8 \%$ used other drugs during pregnancy.

- $24 \%$ of them experience social and family issues about their job and occupation.

- 13\% uses Facebook, 30\% uses Twitter and $37 \%$ uses YouTube.

- $36 \%$ of the participants do sports activities 1 hour a day, 5\% does 2 hours and 7\% does 3 hours during pregnancy.

- Most popular activities are Walking with $13 \%$, Swimming with $30 \%$, Fitness with $37 \%$ and other sports activities with $3 \%$.

- $44 \%$ of them state that sports activities make physical and mental contribution during pregnancy.

- $58 \%$ of them have stated that they are going through a difficult pregnancy.

- $46 \%$ of them have stated that they frequently consult their doctor during pregnancy.
- $56 \%$ of them have uttered to gain weight above normal.

- $72 \%$ of them have said not to prefer $\mathrm{C}$-section if no medical obligation exists.

- $96 \%$ of them have expressed that they know vaginal delivery is a better decision for them.

- $96 \%$ of them have said that doctor has informed about $\mathrm{C}$-section.

- $46 \%$ of them are sufficiently informed about anesthesia and other medical complications.

Factor analysis was applied by evaluating the responses given by the participants. As a result of the analysis, the following factors were obtained. A total of 30 items consisting of the responses of the participants regarding the C-section delivery were loaded on the remaining 4 factorial sub-dimensions after the factor analysis.

1. I prefer C-section due to psychological reasons

2. I prefer C-section due to physiological reasons

3. C-section delivery should be performed upon the mother's request

4. I prefer C-section since healing takes long after vaginal delivery 

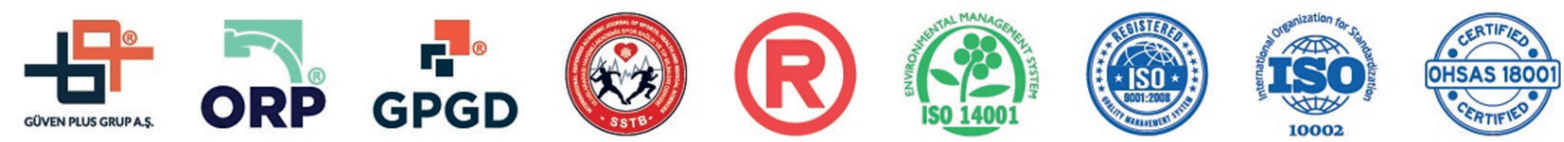

SSTB

www.sstbdergisi.com

International Refereed Academic Journal of Sports, Health and Medical Sciences April - May - June Issue: 35 Spring Summer Term Year: 2020

Uluslararası Hakemli Akademik Spor Sağlık ve Tıp Bilimleri Dergisi

Nisan - Mayıs - Haziran Sayı: 35 İlkbahar Yaz Dönemi Yıl: 2020 ID:486 K:265

ISSN Print: 2146-8508 Online 2147-1711

(ISO 18001-OH-0090-13001706 / ISO 14001-EM-0090-13001706 / ISO 9001-QM-0090-13001706 / ISO 10002-CM-0090-13001706) (TRADEMARK)

(2015/04315- 2015-GE-18972)

Table 4. Component Transformation Matrix

\begin{tabular}{llcccc}
\hline Components & 1 & 2 & 3 & 4 \\
\hline 1. I prefer C-section due to psychological reasons &, 746 &, 576 &, 211 &, 259 \\
\hline 2. & I prefer C-section due to physiological reasons &,- 364 &,- 064 &, 662 &, 652 \\
\hline 3. & C-section delivery should be performed upon the mother's request &,- 374 &, 499 &,- 623 &, 473 \\
\hline 4. & I prefer C-section since healing takes long after vaginal delivery &,- 414 &, 644 &, 360 &,- 533
\end{tabular}

Table 5. Total Variance Explained

\begin{tabular}{|c|c|c|c|c|c|c|c|c|c|}
\hline \multirow[t]{2}{*}{ Components } & \multicolumn{3}{|c|}{ Initial Eigen values } & \multicolumn{3}{|c|}{$\begin{array}{l}\text { Extraction Sums of } \\
\text { Squared Loadings }\end{array}$} & \multicolumn{3}{|c|}{$\begin{array}{l}\text { Rotation Sums of Squared } \\
\text { Loadings }\end{array}$} \\
\hline & Total & $\begin{array}{l}\% \text { of } \\
\text { Vari- } \\
\text { ance }\end{array}$ & $\begin{array}{l}\text { Cumu- } \\
\text { lative } \%\end{array}$ & Total & $\begin{array}{l}\% \text { of } \\
\text { Vari- } \\
\text { ance }\end{array}$ & $\begin{array}{l}\text { Cumu- } \\
\text { lative } \%\end{array}$ & Total & $\begin{array}{l}\% \text { of } \\
\text { Vari- } \\
\text { ance }\end{array}$ & $\begin{array}{l}\text { Cumu- } \\
\text { lative } \%\end{array}$ \\
\hline $\begin{array}{l}\text { 1. I prefer C-section due } \\
\text { to psychological reasons }\end{array}$ & 4,185 & 13,950 & 13,950 & 4,185 & 13,950 & 13,950 & 3,333 & 11,110 & 11,110 \\
\hline $\begin{array}{l}\text { 2. I prefer C-section due } \\
\text { to physiological reasons }\end{array}$ & 2,593 & 8,642 & 22,592 & 2,593 & 8,642 & 22,592 & 2,797 & 9,322 & 20,432 \\
\hline $\begin{array}{l}\text { 3. C-section delivery } \\
\text { should be performed upon } \\
\text { the mother's request }\end{array}$ & 2,266 & 7,553 & 30,145 & 2,266 & 7,553 & 30,145 & 2,461 & 8,202 & 28,634 \\
\hline $\begin{array}{l}\text { 4. I prefer C-section since } \\
\text { healing takes long after } \\
\text { vaginal delivery }\end{array}$ & 2,007 & 6,690 & 36,835 & 2,007 & 6,690 & 36,835 & 2,460 & 8,201 & 36,835 \\
\hline
\end{tabular}

By examining the number of pregnancies and the possibility of having an abortion, the probability of the participants who experienced a large number of pregnancies to terminate the pregnancy process was desired to be determined. The analysis does not reject the hypot- hesis that the probability of abortion does not change as the number of pregnancy of the participants rises, which is the basic hypothesis. Accordingly, the probability of abortion does not change as the number of pregnant women increases. 
www.sstbdergisi.com

International Refereed Academic Journal of Sports, Health and Medical Sciences

April - May - June Issue: 35 Spring Summer Term Year: 2020

Uluslararası Hakemli Akademik Spor Sağlık ve Tıp Bilimleri Dergisi

Nisan - Mayıs - Haziran Sayı: 35 İlkbahar Yaz Dönemi Yıl: 2020 ID:486 K:265

ISSN Print: 2146-8508 Online 2147-1711

(ISO 18001-OH-0090-13001706 / ISO 14001-EM-0090-13001706 / ISO 9001-QM-0090-13001706 / ISO 10002-CM-0090-13001706) (TRADEMARK)

(2015/04315- 2015-GE-18972)

\section{ANOVA}

1. IS THIS YOUR FIRST PREGNANCY

\begin{tabular}{llllll}
\hline & Sum of Squares & df & MeanSquare & F & Sig. \\
\hline BetweenGroups &, 548 & 1 &, 548 &, 855 &, 356 \\
\hline WithinGroups & 274,438 & 428 &, 641 & & \\
\hline Total & 274,986 & 429 & & &
\end{tabular}

By examining the number of pregnancies and nutrition regularly, it was aimed to determine whether the participants who had a large number of pregnancies applied a special diet during pregnancy. The analysis rejects the hypothesis that the nutrition of the participants does not change as the number of pregnancy rises, which is the basic hypothesis. Accordingly, participants apply a special diet as the number of pregnancy increases.

\begin{tabular}{|c|c|c|c|c|c|}
\hline ANOVA & & & & & \\
\hline 1. IS THIS YO & PREGNANCY & & & & \\
\hline & Sum of Squares & $\mathrm{df}$ & MeanSquare & $\mathrm{F}$ & Sig. \\
\hline BetweenGroups & 9,755 & 4 & 2,439 & 3,908 &, 004 \\
\hline WithinGroups & 265,231 & 425 & ,624 & & \\
\hline Total & 274,986 & 429 & & & \\
\hline
\end{tabular}

Analysis was carried out to understand whether substance use such as smoking and alcohol during pregnancy was triggered by a psychological problem. The hypothesis that the substance use of the participants, which is the main hypothesis of the analysis, did not trigger psychological problems was rejected. Accordingly, as the participants use such substances as smoking and alcohol, they are more likely to experience psychological problems. 


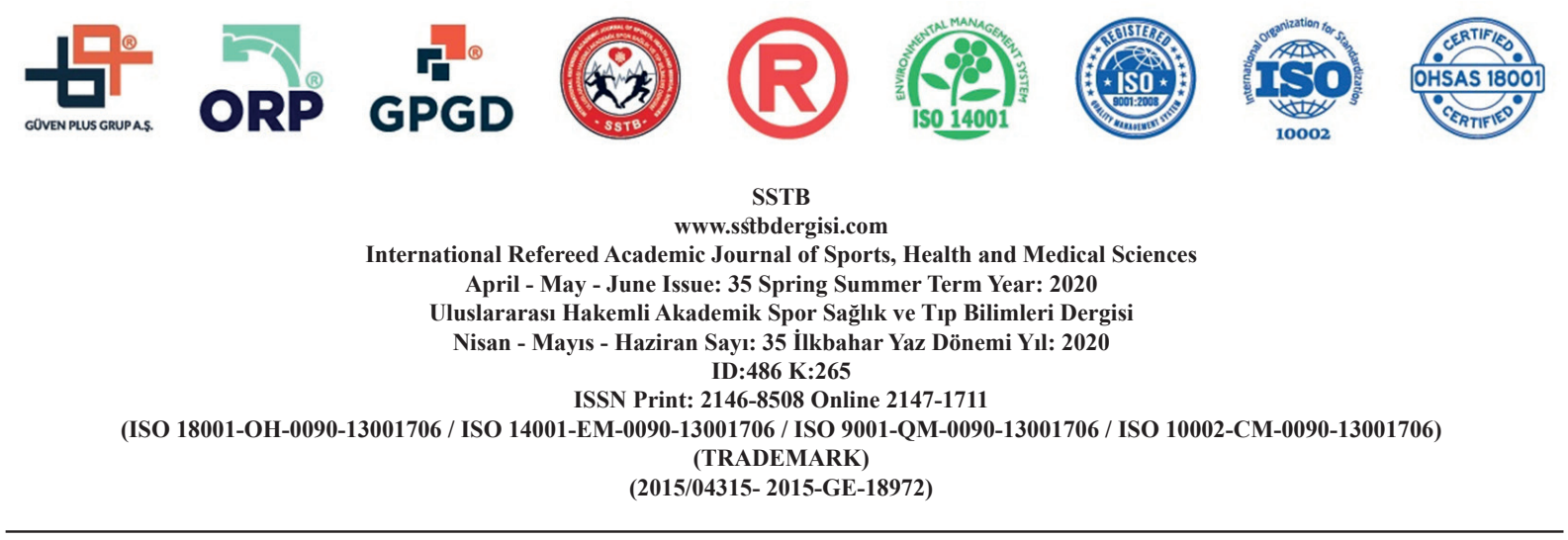

ANOVA

11. WHICH OF THE FOLLOWING ITEMS DO YOU USE CONSISTENTLY?

\begin{tabular}{llllll}
\hline & Sum of Squares & df & MeanSquare & F & Sig. \\
\hline BetweenGroups & 57,001 & 1 & 57,001 & 16,593 &, 000 \\
\hline WithinGroups & 1470,304 & 428 & 3,435 & & \\
\hline Total & 1527,305 & 429 & & &
\end{tabular}

Analysis was carried out to understand whettriggered by a problem at work or social life her the probability of experiencing a psychological problem during pregnancy was triggered by a problem at work or social life. The hypothesis that the probability of participants was rejected, which is the main hypothesis. Accordingly, the psychological problems of the participants are affected by their problems in business or social life.

to experience psychological problem is not

\begin{tabular}{llllll} 
Chi-Square Tests & Value & df & Asymp. Sig. (2-sided) & $\begin{array}{l}\text { ExactSig. } \\
\text { (2-sided) }\end{array}$ & $\begin{array}{c}\text { ExactSig. } \\
\text { (1-sided) }\end{array}$ \\
\hline PearsonChi-Square & & & & & \\
\hline ContinuityCorrectionb & 430,000 & 1 &, 000 &, 000 &, 000 \\
\hline LikelihoodRatio & 424,491 & 1 &, 000 & & \\
\hline Fisher'sExact Test & 471,144 & 1 &, 000 & & \\
\hline Linear-by-LinearAssociation & 429,000 & 1 &, 000 & &
\end{tabular}

Analysis was carried out to understand whether substance use such as smoking and alcohol during pregnancy was triggered by a problem at work or social life. The hypothesis that the substance use is not triggered by problems at work or social life - which is the main hypothesis of the analysis - was rejected. Accordingly, as the probability of participants to use such substances as smoking and alcohol increases as they are more likely to experience problems at work or social life. 

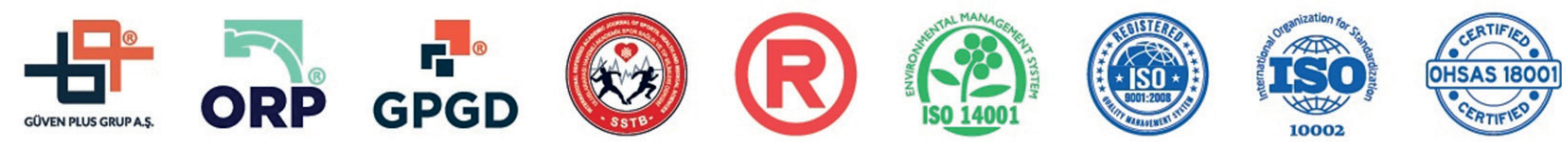

SSTB

www.sstbdergisi.com

International Refereed Academic Journal of Sports, Health and Medical Sciences

April - May - June Issue: 35 Spring Summer Term Year: 2020

Uluslararası Hakemli Akademik Spor Sağlık ve Tıp Bilimleri Dergisi

Nisan - Mayıs - Haziran Sayı: 35 İlkbahar Yaz Dönemi Yıl: 2020 ID:486 K:265

ISSN Print: 2146-8508 Online 2147-1711

(ISO 18001-OH-0090-13001706 / ISO 14001-EM-0090-13001706 / ISO 9001-QM-0090-13001706 / ISO 10002-CM-0090-13001706) (TRADEMARK)

(2015/04315- 2015-GE-18972)

\begin{tabular}{llll} 
Chi-Square Tests & Value & df & Asymp. Sig. (2-sided) \\
\hline PearsonChi-Square & 24,597 & 4 &, 000 \\
\hline LikelihoodRatio & 29,863 & 4 &, 000 \\
\hline Linear-by-LinearAssociation & 16,011 & 1 &, 000 \\
\hline N of ValidCases & 430 & &
\end{tabular}

An analysis was carried out to find out whether informing the patient by the doctor who will perform delivery during pregnancy increases the likelihood of normal delivery of the patient. The main hypothesis of the analysis states that the doctor's detailed information about the cesarean section to the patient does not affect the possibility of normal delivery. As a result of the analysis, it was determined that informing the patient about the positive or negative effects of cesarean during pregnancy increases the probability of normal delivery.

Independent Samples Test

Levene's Test t-test for Equality of Means

for Equality of

Variances

\begin{tabular}{|c|c|c|c|c|c|c|c|c|c|c|}
\hline & \multirow{3}{*}{$\mathrm{F}$} & \multirow{3}{*}{ Sig. } & \multirow{3}{*}{$\mathrm{t}$} & \multirow{3}{*}{ df } & \multirow{3}{*}{$\begin{array}{l}\text { Sig. } \\
\text { (2-tailed) }\end{array}$} & \multirow{3}{*}{$\begin{array}{l}\text { Mean } \\
\text { Differ- } \\
\text { ence }\end{array}$} & \multirow{3}{*}{$\begin{array}{l}\text { Std. Er- } \\
\text { ror Dif- } \\
\text { ference }\end{array}$} & & \\
\hline & & & & & & & & & \multicolumn{2}{|c|}{$\begin{array}{l}95 \% \text { Confidence } \\
\text { Interval of the Dif- } \\
\text { ference }\end{array}$} \\
\hline & & & & & & & & & Lower & Upper \\
\hline \multirow{2}{*}{$\begin{array}{l}\text { 23. DO YOU } \\
\text { KNOW THAT } \\
\text { VAGINAL } \\
\text { BIRTH IS A } \\
\text { BETTER DE- } \\
\text { CISION FOR } \\
\text { YOU? }\end{array}$} & $\begin{array}{l}\text { Equal variances } \\
\text { assumed }\end{array}$ & 21,457 & ,000 & $-2,597$ & 428 &, 010 &,- 12783 & 04921 &,- 22456 &,- 03110 \\
\hline & $\begin{array}{l}\text { Equal variances } \\
\text { not assumed }\end{array}$ & & & $-1,406$ & 17,380 & ,177 &,- 12783 & ,09089 &,- 31927 & ,06361 \\
\hline
\end{tabular}

An analysis was performed to understand whether the pregnant women's age is an effective factor on $\mathrm{C}$-section preference. The main hypothesis of the analysis states that pregnant women's age does not affect C-section preferences. Following the analysis, it has been determined that the pregnant women's age is an effective factor on the following statements; 
www.sstbdergisi.com

International Refereed Academic Journal of Sports, Health and Medical Sciences April - May - June Issue: 35 Spring Summer Term Year: 2020

Uluslararası Hakemli Akademik Spor Sağlık ve Tıp Bilimleri Dergisi

Nisan - Mayıs - Haziran Sayı: 35 İlkbahar Yaz Dönemi Yıl: 2020

ID:486 K:265

ISSN Print: 2146-8508 Online 2147-1711

(ISO 18001-OH-0090-13001706 / ISO 14001-EM-0090-13001706 / ISO 9001-QM-0090-13001706 / ISO 10002-CM-0090-13001706) (TRADEMARK)

(2015/04315- 2015-GE-18972)

preferring C-section due to psychological and physiological reasons, $\mathrm{C}$-section delivery must be performed upon the mother's request and preferring $\mathrm{C}$-section due to long healing process of vaginal delivery.

\begin{tabular}{|c|c|c|c|c|c|c|}
\hline \multicolumn{7}{|l|}{ ANOVA } \\
\hline & & $\begin{array}{l}\text { Sum of } \\
\text { Squares }\end{array}$ & $\mathrm{df}$ & MeanSquare & F & Sig. \\
\hline \multirow[t]{3}{*}{$\begin{array}{l}\text { I prefer C-section due to psychologi- } \\
\text { cal reasons }\end{array}$} & $\begin{array}{l}\text { Between- } \\
\text { Groups }\end{array}$ & 17,511 & 5 & 3,502 & 3,609 & ,003 \\
\hline & WithinGroups & 411,489 & 424 & 970 & & \\
\hline & Total & 429,000 & 429 & & & \\
\hline \multirow[t]{3}{*}{$\begin{array}{l}\text { I prefer C-section due to physiologi- } \\
\text { cal reasons }\end{array}$} & $\begin{array}{l}\text { Between- } \\
\text { Groups }\end{array}$ & 29,558 & 5 & 5,912 & 6,275 &, 000 \\
\hline & WithinGroups & 399,442 & 424 & ,942 & & \\
\hline & Total & 429,000 & 429 & & & \\
\hline \multirow[t]{3}{*}{$\begin{array}{l}\text { C-section delivery should be per- } \\
\text { formed upon the mother's request }\end{array}$} & $\begin{array}{l}\text { Between- } \\
\text { Groups }\end{array}$ & 206,854 & 5 & 41,371 & 78,963 &, 000 \\
\hline & WithinGroups & 222,146 & 424 &, 524 & & \\
\hline & Total & 429,000 & 429 & & & \\
\hline \multirow[t]{3}{*}{$\begin{array}{l}\text { I prefer C-section since healing takes } \\
\text { long after vaginal delivery }\end{array}$} & $\begin{array}{l}\text { Between- } \\
\text { Groups }\end{array}$ & 11,532 & 5 & 2,306 & 2,343 &, 041 \\
\hline & WithinGroups & 417,468 & 424 & ,985 & & \\
\hline & Total & 429,000 & 429 & & & \\
\hline
\end{tabular}

An analysis was performed to understand whether pregnant women's education is an effective factor on C-section preferences. The main hypothesis of the analysis states that pregnant women's education does not affect $\mathrm{C}$-section preferences. Following the analysis, it has been determined that pregnant women's education is an effective factor on the following items; preferring $\mathrm{C}$-section due to psychological and physiological reasons, preferring $\mathrm{C}$-section due to long healing process of vaginal delivery. 
www.sstbdergisi.com

International Refereed Academic Journal of Sports, Health and Medical Sciences

April - May - June Issue: 35 Spring Summer Term Year: 2020

Uluslararası Hakemli Akademik Spor Sağlık ve Tıp Bilimleri Dergisi

Nisan - Mayıs - Haziran Sayı: 35 İlkbahar Yaz Dönemi Yıl: 2020 ID:486 K:265

ISSN Print: 2146-8508 Online 2147-1711

(ISO 18001-OH-0090-13001706 / ISO 14001-EM-0090-13001706 / ISO 9001-QM-0090-13001706 / ISO 10002-CM-0090-13001706) (TRADEMARK)

(2015/04315- 2015-GE-18972)

\begin{tabular}{|c|c|c|c|c|c|c|}
\hline \multicolumn{7}{|l|}{ ANOVA } \\
\hline & & $\begin{array}{l}\text { Sum of } \\
\text { Squares }\end{array}$ & $\mathrm{df}$ & MeanSquare & $\mathrm{F}$ & Sig. \\
\hline \multirow{3}{*}{$\begin{array}{l}\text { I prefer C-section due to psycho- } \\
\text { logical reasons }\end{array}$} & BetweenGroups & 52,959 & 4 & 13,240 & 14,964 &, 000 \\
\hline & WithinGroups & 376,041 & 425 &, 885 & & \\
\hline & Total & 429,000 & 429 & & & \\
\hline \multirow{3}{*}{$\begin{array}{l}\text { I prefer C-section due to physi- } \\
\text { ological reasons }\end{array}$} & BetweenGroups & 16,067 & 4 & 4,017 & 4,134 &, 003 \\
\hline & WithinGroups & 412,933 & 425 & ,972 & & \\
\hline & Total & 429,000 & 429 & & & \\
\hline \multirow{3}{*}{$\begin{array}{l}\text { C-section delivery should be per- } \\
\text { formed upon the mother's request }\end{array}$} & BetweenGroups & 7,896 & 4 & 1,974 & 1,992 & ,095 \\
\hline & WithinGroups & 421,104 & 425 & ,991 & & \\
\hline & Total & 429,000 & 429 & & & \\
\hline \multirow{3}{*}{$\begin{array}{l}\text { I prefer C-section since healing } \\
\text { takes long after vaginal delivery }\end{array}$} & BetweenGroups & 11,807 & 4 & 2,952 & 3,007 & ,018 \\
\hline & WithinGroups & 417,193 & 425 & ,982 & & \\
\hline & Total & 429,000 & 429 & & & \\
\hline
\end{tabular}

An analysis was performed to understand whether pregnant women's income is an effective factor on $\mathrm{C}$-section preferences. The main hypothesis of the analysis states that pregnant women's income does not affect $\mathrm{C}$-section preferences. Following the analy- sis, it has been determined that pregnant women's income is an effective factor on the following items; preferring $\mathrm{C}$-section due to psychological and physiological reasons and C-section delivery must be performed upon the mother's request. 


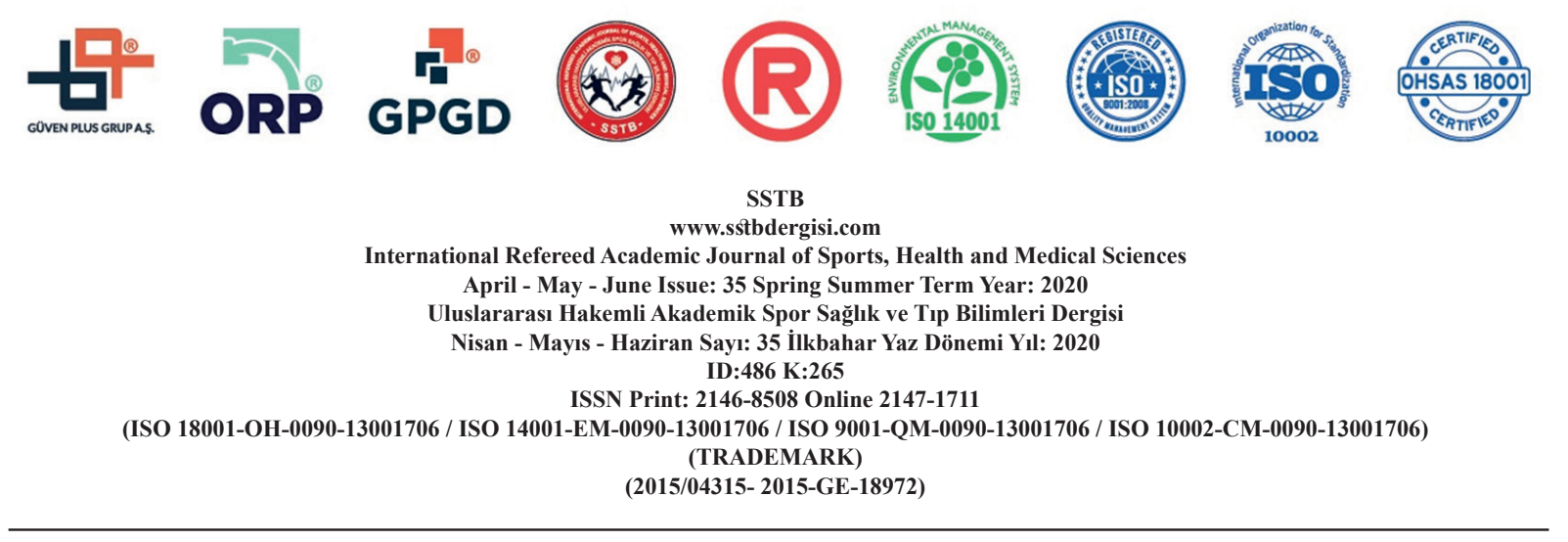

\begin{tabular}{|c|c|c|c|c|c|c|}
\hline \multicolumn{7}{|l|}{ ANOVA } \\
\hline & & $\begin{array}{l}\text { Sum of } \\
\text { Squares }\end{array}$ & $\mathrm{df}$ & MeanSquare & $\mathrm{F}$ & Sig. \\
\hline \multirow{3}{*}{$\begin{array}{l}\text { I prefer C-section due to psycho- } \\
\text { logical reasons }\end{array}$} & BetweenGroups & 29,787 & 4 & 7,447 & 7,928 &, 000 \\
\hline & WithinGroups & 399,213 & 425 & ,939 & & \\
\hline & Total & 429,000 & 429 & & & \\
\hline \multirow{3}{*}{$\begin{array}{l}\text { I prefer C-section due to physi- } \\
\text { ological reasons }\end{array}$} & BetweenGroups & 92,878 & 4 & 23,220 & 29,359 &, 000 \\
\hline & WithinGroups & 336,122 & 425 &, 791 & & \\
\hline & Total & 429,000 & 429 & & & \\
\hline \multirow{3}{*}{$\begin{array}{l}\text { C-section delivery should be per- } \\
\text { formed upon the mother's request }\end{array}$} & BetweenGroups & 19,688 & 4 & 4,922 & 5,111 &, 000 \\
\hline & WithinGroups & 409,312 & 425 & ,963 & & \\
\hline & Total & 429,000 & 429 & & & \\
\hline \multirow{3}{*}{$\begin{array}{l}\text { I prefer } \mathrm{C} \text {-section since healing } \\
\text { takes long after vaginal delivery }\end{array}$} & BetweenGroups & 6,767 & 4 & 1,692 & 1,703 & ,148 \\
\hline & WithinGroups & 422,233 & 425 & ,993 & & \\
\hline & Total & 429,000 & 429 & & & \\
\hline
\end{tabular}

\section{CONCLUSION}

Women who prefer cesarean surgery are more likely to have experienced this type of birth before and experience negative emotions about it. To reduce women's C-section preference, practitioners should reduce the rate of primary cesarean delivery and improve the quality of emotional care for women who require cesarean delivery. Caregivers should have a delicate discussion about the risks and benefits of various delivery options, including vaginal delivery after cesarean, with women who have had a cesarean delivery before deciding about the way of delivery during a later pregnancy. At the end of the study, it was found that the probability of abortion did not change with the increase in the number of pregnancies and they applied a special diet. It has been determined that participants are more likely to experience psychological problems related to the increased use of substances such as smoking and alcohol, and these problems are affected by problems in business or social life, as well as they are more likely to experience problems in business or social life, they are also more likely to use substances such as smoking and alcohol.

It has been determined that informing patients during pregnancy about the positive or negative effects of C-section delivery increases the probability of vaginal delivery and the pregnant women's income is an effective fac- 
International Refereed Academic Journal of Sports, Health and Medical Sciences April - May - June Issue: 35 Spring Summer Term Year: 2020

Uluslararası Hakemli Akademik Spor Sağlık ve Tıp Bilimleri Dergisi

Nisan - Mayıs - Haziran Sayı: 35 İlkbahar Yaz Dönemi Yıl: 2020 ID:486 K:265

ISSN Print: 2146-8508 Online 2147-1711

(ISO 18001-OH-0090-13001706 / ISO 14001-EM-0090-13001706 / ISO 9001-QM-0090-13001706 / ISO 10002-CM-0090-13001706) (TRADEMARK)

(2015/04315- 2015-GE-18972)

tor on the items of preferring C-section due to psychological and physiological reasons, C-section delivery must be performed upon the mother's request and preferring C-section due to long healing process of vaginal delivery.

\section{REFERENCES}

BAŞARA, B.B., GÜLER, C., ERYILMAZ, Z., YENTÜR, G.K., PULGAT, E., (2012). TC Sağlık Bakanlığı Sağlık İstatistikleri Y1llığı 2011. Sağlık Araştırmaları Genel Müdürlüğü, Sağlık Bakanlığı. Ankara: Semih Ofset Matbaacılık, p.54.

BAYÜM, S., DINCCER, N.C., ÇERÇI, S., (2014). Kadın bakış açısıyla sezeryan,Hukuk Gündemi, 1, Accessed: http://www.ankarabarosu.org.tr/siteler/ ankarabarosu/hgdmakale/2014-1/18.pdf, Accessed: 12.12.2019

DÖLEN, İ., ÖZDEĞİRMENCİ, Ö., (2004). Optimal sezaryen hizı ne olmalıdır? Türkiye'de ve dünyada güncel nedir?. Türk Jinekoloji ve Obstetrik Derneği Dergisi, 1(2): 113-117.

ELKIN, N., (2016). Bir Aile Sağlığ1 Merkezine Başvurmuş Olan 18-49 Yaş Arası Kadınların Doğum Şekli Tercihleri ve İlişkili Faktörler, Anadolu Kliniği, Cilt 21, Say1 2

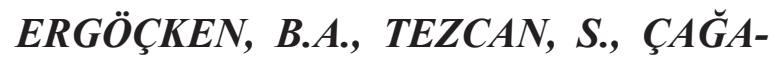
TAY, P., (2009). Üreme Sağlığı. Türkiye Nüfus ve Sağlık Araştırması, Hacettepe Üniversitesi Hastaneleri Basımevi, Ankara, pp.152.

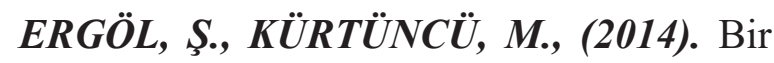
Üniversite Hastanesinde Kadınların Sezaryen Doğum Tercihlerini Etkileyen Faktörler, Hacettepe Üniversitesi Hemşirelik Fakültesi Dergisi, 26-34

GÖZÜKARA, F., EROĞLU, K., (2008). İlk doğumunu yapmış kadınların (primipar) doğum şekline yönelik tercihlerini etkileyen faktörler. Sağlık Bilimleri Fakültesi Hemşirelik Derg. 15(1):32-46.

KARABEL, M.P., DEMIRBAŞ, M., INCİ, M.B., (2017). Türkiye'de ve Dünya'da Değişen Sezaryen S1klığı ve Olası Nedenleri, Sakarya Tip Dergisi, 7(4):158163

KARABULUTLU, Ö., (2012). Kadınların Doğum Şekli Tercihlerini Etkileyen Faktörler, İ.Ü.F.N. Hem. Derg, Cilt 20 - Say1 3: $210-218$

KASAI, K.E., (2010). Women's opinions about mode of birth in Brazil: A qualitative study in a public teaching hospital. Midwifery, 26: 319-26

SAYINER, F.D., ÖZERDOĞAN, N., (2009). Doğal doğum. Maltepe Üniversite- 
International Refereed Academic Journal of Sports, Health and Medical Sciences April - May - June Issue: 35 Spring Summer Term Year: 2020

Uluslararası Hakemli Akademik Spor Sağlık ve Tıp Bilimleri Dergisi

Nisan - Mayıs - Haziran Sayı: 35 İlkbahar Yaz Dönemi Yıl: 2020 ID:486 K:265

ISSN Print: 2146-8508 Online 2147-1711

(ISO 18001-OH-0090-13001706 / ISO 14001-EM-0090-13001706 / ISO 9001-QM-0090-13001706 / ISO 10002-CM-0090-13001706) (TRADEMARK)

(2015/04315- 2015-GE-18972)

si Hemşirelik Bilim ve Sanatı Dergisi, 2(3):143-148

SÖNMEZ, C.I., SİVASLIOĞLU, A.A., (2019). Gebe Kadınların Doğum Şekli Tercihi ve Bunları Etkileyen Faktörler, Konuralp Tip Dergisi, 11(3): 369-376

T.C. (2014). Sağlık Bakanlığı. Stratejik Plan 2013-2017. Ankara. 2012. http://sbu. saglik.gov.tr/Ekutuphane/kitaplar/stratejikplanturk.pdf Accessed: 20.12.2014

TNSA, (2008). Hacettepe Üniversitesi Nüfus Etütleri Enstitüsü, Sağlık Bakanlığı Ana Çocuk Sağlığı/Aile Planlaması Genel Müdürlüğü ve Devlet Planlama Teşkila- t1. Türkiye Nüfus ve Sağlık Araştırması (TNSA), (2008). Ankara-Türkiye Nüfus ve Sağlık Araştırması 2008 Verileri.

TEKIN, Y.C., (2006). Sezaryenle ve vajinal yolla doğum yapan kadınların doğum öncesi ve sonrası tecrübe ve bilgi düzeylerinin değerlendirilmesi. Doğum ve Kadın Hastalıkları Hemşireliği Anabilim Dalı. Yüksek Lisans Tezi. Afyon

\section{INTERNET RESOURCES}

http://www.hips.hacettepe.edu.tr/eng/ tdhs13/report/TDHS2013_Results_ Izmir_05022015.pdf, Accessed: 11.12.2019 